\title{
VOLTAGE STABILIZATION OF A THREE-PHASE INDUCTION MACHINES CONNECTED AS A SINGLE-PHASE GENERATOR
}

\author{
M.EL-SHEBINY \\ Department of Electrical Engineering, Faculty of lingineering, Menoufiya \\ Iniversity, Shebin El-Kom, EC;)PT.
}

\section{ABSTRACT}

In remote areas and high zone situations it is necessary to use a singlephase generator to be employed as a standby unit, where a single wire carth refurn system is found to be economical to install.

In this paper, a three-phase: induction machine is connected as an isolated self-excited single-phase generator. The possibility of operating this generator through the use of an excited capacitor is outlined. The effect of the excited capacitor is obtained for loaded and unloaded operations. The cxperimental system is used to study the effect of gencrator speed on its loading of the generator. Moreover the output voltage of the generator is stabilized using the designed parametes for a fixed capacitor thyristor controlled inductor scheme. This scheme is used to regulate the generator terminal voltage by controlling the thyristors firing angle. This is done by adjusting the self excitation to maintain the terminal votlage constant over a wide range of loading.

Manuscript received from Dr. M.EL-SHEBINY on : $8 / 3 / 1999$

Accepted on : $25 / 3 / 2000$

Engineering Research Bulletin, Vol 23,No 2, 2000 Minufiya University, Faculty of Engineering, Shebien El-Kom , Egypt, ISSN 1110-1180 
LIS OF MAIN SYMBOLES:

$\begin{array}{ll}C_{1}, C, & : \text { Excitation and balancer capacitance. } \\ C_{1} & : \text { Compensator capacitance. } \\ & \text { : Controlled inductarce. } \\ I_{1}, I_{13}, I_{1} & : \text { Winding currents. } \\ Z_{1} & : \text { Load impedance. } \\ & : \text { Load phase angle. } \\ & : \text { Angular frequency. }\end{array}$

\section{INTRODUCTION}

The induction machines have many advantages such as low cost, robustness and the elimination of maintenance problem. To obtain reater output rating, the three-phase induction machine is used as an isolated self-excited single-phase induction genertor in which the output power rating is limited in single-phase induction machine.

The induction machines can be self-excited when a suitable capacitor is connected across its winding. This phenomenon is extensively exploited in power generation schemes which employ renewable energy resources such as hydro, wind, and biogas, where there are obvious advantages in using the squirrel-cage induction machine in preference to the conventional sy nchronous machines as the electromechanical energy converter.

Considerable attempts have heen made to study the steady-state and transient performance of three-phase self excited induction generators |1-8|. However, some attempts |9-12| have been made on the analysis of capacitor exited single-phase induction generator, in spite of their various small scale applications, specially at remote places or above mountains in small towns. In Reference |10|, a method for analy zing the steady-state performance of a single-phase self-excited induction generator which supplies an isolated resistive load is described. In reference $|9|$, tho performance of an isolated self-excited single-phase induction generator when the excitation capacitor is connected to one winding and the load is connected to the other. The simulation is depending upon the quiralent circuit to study the steady-state performance. The modelling and steadystate performance of a single-phase induction generator feeding an R-I. loal including saturation effect is reported in reference 1111. The performances of self-excited single-phase induction generators with shunt, short-shunt and long-shunt excitation connections are reported in reference $|12|$.

The need for alternative and renewable energs sources for utility and autonomous applications especially in remote places has focused on the use of single-phase generators. In high zones which are in the top of mountains, a single-phase is used instead of threc-phases. Therefore, the 
single phase genertors are used as a standby for generating the electric power when the main electric supply is off.

The rating of single-phase induction generators are limited for greater output rating induction generators. Thus, the three-phase induction machines are connected as an isolated self-excited single-phase generators to obtain high power ratings for these places which employs a singlephase supply.

In this paper, the steady-state performances of a three-phase induction machine connected as an isolated self-excited single-phase gnerator are obtained experimentally. The effect of excitation and balancer capacitor is obtained with unloaded and loaded generator with different drive speeds. The output votlage is stabilized using thyristor controlled inductor parallel with the capcitor as a type of votlage regulating system. The suitable parameters of the voltage regulating circuit are designed to obtain stabilized load voltage.

\section{SYSTEM CONFIGURATION}

Figure (1) shows the system configuration. It consists of a three-phase induction machines connected as a self excited single-phase generator supplying an isolated load. The generator is driven by a d.c motor as a prime-mover. A fixed capacitor-thyristor controlled inductor is used to stabilize the output voltage [13].

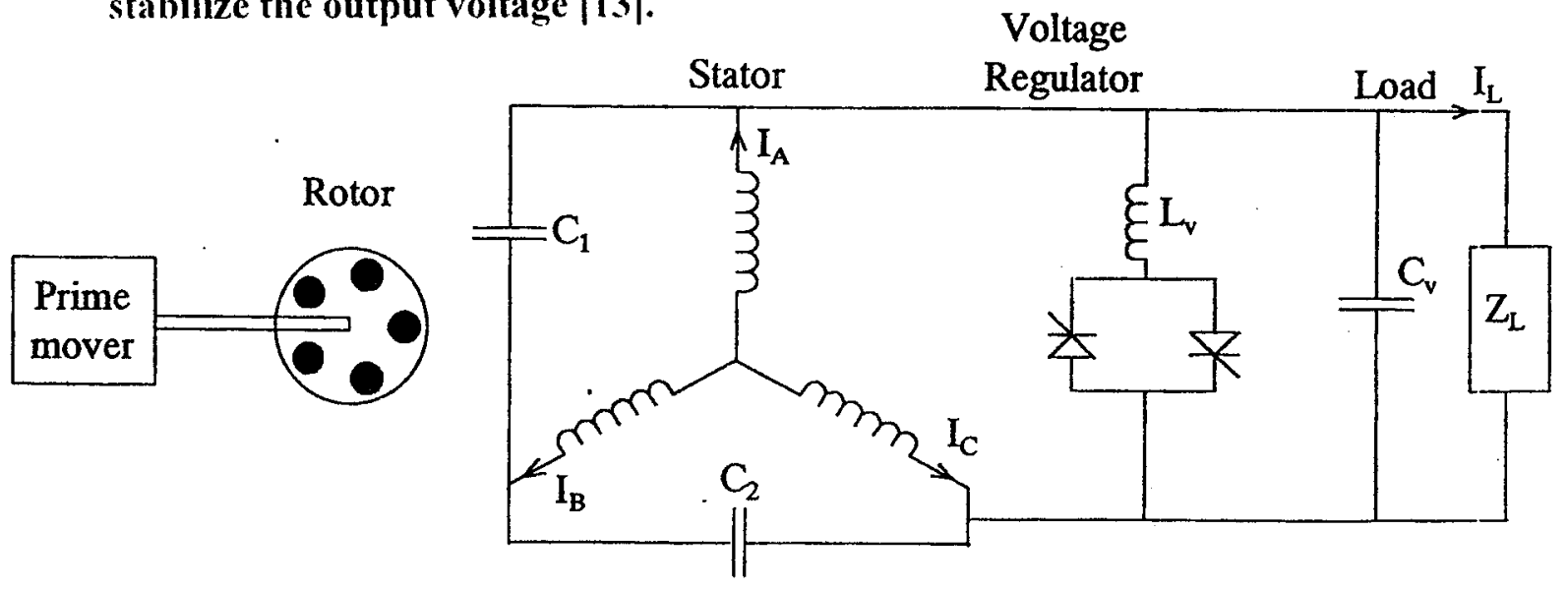

Figure (1): Three-phase induction machine connceted as an isolated self excited single-phase induction generator coupled with the prime mover.

\section{DESIGN OF VOLTAGE REGULATOR PARAMETERS}

The value of inductor inductance $\left(L_{v}\right)$ and capacitor capacitance $\left(C_{v}\right)$ of the fixed capacitor thy ristor controlled inductor are selected according to the following relationship |14|: 


$$
{ }_{0} C_{v}=1 /(1) L_{v}=1 / Z_{1} \sin \phi_{1}
$$

where, (1) is the angular frequency,

$Z_{1}$. is the load impedance and,

$\phi_{1}$. is the load phase angle.

The parameters value of the designed votlage regulator for the load are:

$$
C_{1}=30 \mu \mathrm{F} \quad, \quad \mathrm{L}_{v}=0.0060 \text { Henry. }
$$

The test machine used is a three-phase, $50 \mathrm{~Hz}, 1+20 \mathrm{r} \cdot \mathrm{p} . \mathrm{m}$, squirrel-cage, 2-HP, 4-pole, 380/220 volt, 3.6/6.2 ampere, star/delta connected induction motor. the measured parameters at $50 \mathrm{~Hz}$ are:

Stator phase resistance $=4.7 \mathrm{ohm}$.

Stator phase leakage reactance $=7.5 \mathrm{ohm}$.

Rotor phase resistance referred to stator side $=1.4 \mathrm{ohm}$.

Rotor phase leakage reactance referred to stator side $=7.5 \mathrm{ohm}$.

Magnetizing reactance $=100 \mathrm{ohm}$.

\section{OPEN CIRCUIT CHARACTERISTICS}

Figure (2) shows the variation of the open circuit terminal voltage with the excitation capacitance $C_{1}$ without voltage regulation $\left(C_{v}=0, L_{1}=0\right)$. In (a) the rotor speed is $1100 \mathrm{rpm}$ while in (b) it is $1000 \mathrm{rpm}$. The results reveals that the terminal voltages are increased with increasing rotor speed.

The variations of terminal volrages and winding currents versus rotor speed without voltage regulator $\left(\mathrm{C}_{\mathrm{V}}=0 \mu \mathrm{F}\right.$ and $\left.\mathrm{L}_{\mathrm{V}}=0 \mathrm{H}\right)$ are shown in Figures $(3 \& 4)$ respectively, when the machine is cxcited through the capacitance $\mathrm{C}_{1}=44 \mu \mathrm{F}, \mathrm{C}_{2}=0 \mu \mathrm{F}$.

Figure $(5 a, b, c)$ shows the effecl of connecting the halancer capacitance ( 2 on the open circuit charactersitics without voltage regulator $\left(C_{,}=\mathbf{0}\right.$, $\left.L_{1}=()\right)$. It shows the variations of the terminal voltages versus rotor speed for two different combination values of excitation and balancer capacitances. $\left(\mathrm{C}_{1}=44 \mu \mathrm{F}, \mathrm{C}_{2}=20 \mu \mathrm{F}\right)$ and $\left(\mathrm{C}_{1}=39^{\circ} \mu \mathrm{F}, \mathrm{C}_{2}=25 \mu \mathrm{F}\right)$. These selected values are chosen experimentally to give suitable values of terminal votlages and winding currents not to evecell the machine rated values.

It is noticed that the terminal voltages are higher than that obtained without balancer capacitance. This is due to the increased values of the excitation capacitances. 
Figure (6) shows the variations of the winding currents versus motor speed with $C_{1}=44 \mu F, C_{2}=20 \mu F, C_{r}=0 \mu F$ and $L_{1}=0 \mathrm{H}$.

\section{LOAD CHARACTERISTICS}

Results of load tests on the machine for unity power factor and different values of rotor speed without voltage regulation with $C_{1}=0 \mu \mathrm{F}, L_{1}=0 \mathrm{H}, C_{1}=10 \mu \mathrm{F}$ and $C_{2}=44 \mu \mathrm{F}$ are shown in Figure (7). The terminal votlage decreases $w$ ith increased load current and more power can be extracted from the machine with increasing speed.

Figure (8) shows the load characteristics curves for unity power factor and rotor speed 1000 r.p.in. Curve (1) for $C_{v}=0 \mu \mathrm{F}, \mathrm{L}_{\mathrm{v}}=0 \mathrm{H}$, $C_{1}=10 \mu F$ and $C_{2}=44 \mu F$. Curve (2) for $C_{1}=0 \mu F, L_{1}=0 \mathrm{H}, C_{1}=44 \mu F$, and $C_{2}=0 \mu \mathrm{F}$. It is observed that there is a great reduction in the output voltage and current (power) when halancer capacitance is not used.

Figure (9) shows the load characteristics cuves for unity power factor and rotor speed of 900 r.p.m. for different values of excitation and balancer capacitances $\left(C_{1}=10 \mu \mathrm{F}\right.$ and $\left.C_{2}=42 \mu \mathrm{F}\right)$ for curve 1 and $\left(C_{1}=15 \mu \mathrm{F}\right.$ and $\left.C_{2}=49 \mu F\right)$ for curve 2 . Both curves are obtained without voltage regulation $\left(C_{\mathrm{v}}=0 \mu \mathrm{F}\right.$ and $\left.\mathrm{L}_{\mathrm{v}}=0 \mathrm{H}\right)$ The curves are almost parallel, indicating a proportional increase in terminal votlage with excitation and balancer capacitances.

Figure (10) shows the load characteristics of the machine without voltage regulation $\left(C_{i}=0 \mu \mathrm{F}\right.$ and $\left.L_{v}=0 \mathrm{H}\right)$ for different values of power factor with rotor speed (1000 r.p.m.) and excitation, balancer capacitances of $C_{1}=10 \mu \mathrm{F}$, and $C_{2}=44 \mu \mathrm{F}$. It is noticed that very slight reduction in power factor causes high dropping effects on the load charcersitcis and great reductions in the output power.

\section{IMPROVEMENT OF THE LOAD CHARACERISTICS}

Thy ristor controlled inductor voltage regulator system is used to improve the load charactersitics. The terminal voltage of the self excited machine, connected as single phase generator, can be maintained to a constant value if a fixed value of capacitor bank and thy ristor controlled inductor are used in parallel while controlling the firing angle of thyristors as shown in Figure (1).

Figure (11) shows the load characteristic curves for 0.8 power factor las., motor speed 1000 r.p.m. and excitation and balancer capacitance are $C_{1}=10 \mu \mathrm{F}$ and $C_{2}=44 \mu \mathrm{F}$ respectively. Curve (1) for the system without votlage regulator $\left(C_{1}=0 \mu F, L_{1}=0 \mathrm{H}\right)$, curve (2) for the system with 
voltage regulator $\left(C_{v}=30 \mu F . L_{v}=0.006 \mathrm{H}\right)$. It is clear that the improvement of the output voltage is due to using of the voltages regulator.

Figure (12) shows the generator terminal voltage versus load current when voltage regulator is employed. It is clear that the terminal voltage is approximately constant and equal.

\section{CONCLUSIONS}

In this paper the proposed system consists of a three-phase induction machine connected as an isolated self-excited single-phase generator with and without phase balancer capacitor. This system can be used as a standby unit in remote areas, where a single wire earth return system is used to be economical to install.

From the results obtained at st'ady-state, the following conclusions are summarized:

- The terminal voltages are increased with increasing motor speed for noload and load characteristics.

- The terminal voltages and power are increased with using balancer capacitance for no-load and load charaacteristics.

- The terminal voltage is decreased with increasing load current.

- Load power extracted is increased with increasing the speed.

- The reduction of load power factor causes high dropping effects on the load characteristics and great reduction in the output power.

- The generator terminal votlage can be maintained at constant value for a load variations using fixed capacitor-thyristor controlled inductor as a voltage regualtor.

- The generator terminal voltage is approximately constant using voltage regulator.

\section{REFERENCES}

11) S.S. Murthy, O.P. Malik and A.K. Tandon, "Inalysis of Self-Excited Induction Gencrators", IEF Proc. (., Vol. 129, Vo.6, 1982, pp. 26026.5 .

|2| L. Ouazene and (i. Mc Pherson, "Analysis of The Isolated Induction Generator", IEEE Trans., vol. PAS-102, No. 8, 1983, pp. 2793-2797.

|3| J.M. Edlter, J.J. boys and .1. Woodword, "Sclf-Excited Induction Machine as a Small Low Coast Generator", IEEE Proc. C., Vol. 131, 1984, pp. 33-41. 
IH S.S. Murthy, H.S. Nagara, and A. Kuryan, "Design Based Computational Procedure for Performance Prediction and Analysis of Self-Excited Induction Generator Using Motor Packages", IEF. Proc. B, Vol. 135, No. 1, 1988, pp. 8-16.

[5] S.S. Murthy and B.P. Singth, "Studies of the Ise of conventional Induction Motors as Self-lixcited Induction (ienerator", IEEE Trans. on EC, Vol. 135, No. 4, 1988, pp. 842-848.

(6) Y.H.A. Rahim, A.L. Mohamadein, A.S. Al-Khalaf, "Comparison Between the Steady-State Psrformance of Self-Excited Reluctance and Induction Generator", IEEE Trans. on EC., Vol. 5, No.3, 1990, pp. 519-525.

|7| (. Cirantham, D. Sutano, and B. Mismail, "Steady-State and Transient Analysis of Self-Excited Induction Generators", IEE Proc. B, Vol. 1.36, No.2, 1989, pp. 61-68.

$|8|$ M.S. Vicatos, and J.A. Tegopoulos, "Transients State Analysis of doubly Fed Induction Generators Inder Three-Phase Short Circuit", IEEE Trans. on EC., Vol. 6, No.1, 1991, pp. 62-6\%.

|9| Y.H.A. Rahim, A.I. Alolah and R.I. Al-Mudaiheem, "Performance of Single-Phase Induction Generators", IEEE Trans. on EC., Vol.8, No.3, Sept., 1993, pp. 389-395.

110] T.F. Chan, "Analysis of Single-Phase Self-Excited Induction Generator", Electric Machine and Power Systems, 23, 1995, pp. 149 162.

[11] O. Ojo, "Performance of Self-Excited Single-Phase Induction Generators With Shunt, Short-Shunt and Long-Shunt Excitation Connections", IEEE Trans. on EC., No.3, Sept., 1996, pp. 254-260.

12| 0. Ojo, "Performance of Self-Excited Single-Phase Induction (ienerator With Shunt, Short-Shunt and Long-Shunt Excitation Connections", IEEE Trans. on EC, No.3, Sept., 1996, pp. 477-482.

[13] L. Gyugyi, and E.R. Taylor, "Characteristic of Static ThyristorControlled Shunt Compensators For Power Transmission System Applications", IEFE Trans. on PAS, Vol. 99, No.5, Sept/Oct. 1980, pp. 1795-1804.

|14| S.F. Haque, N.H. Malik and W. Shepherd, "Operation of a Fixed (apacitor-Thy ristor Controlled Reactor (FC-TCR) Power Factor (ompensator", IFEF Trans. PAS, Vol. PAS-104, No.6, June, 1985, pp. 1385-1390. 

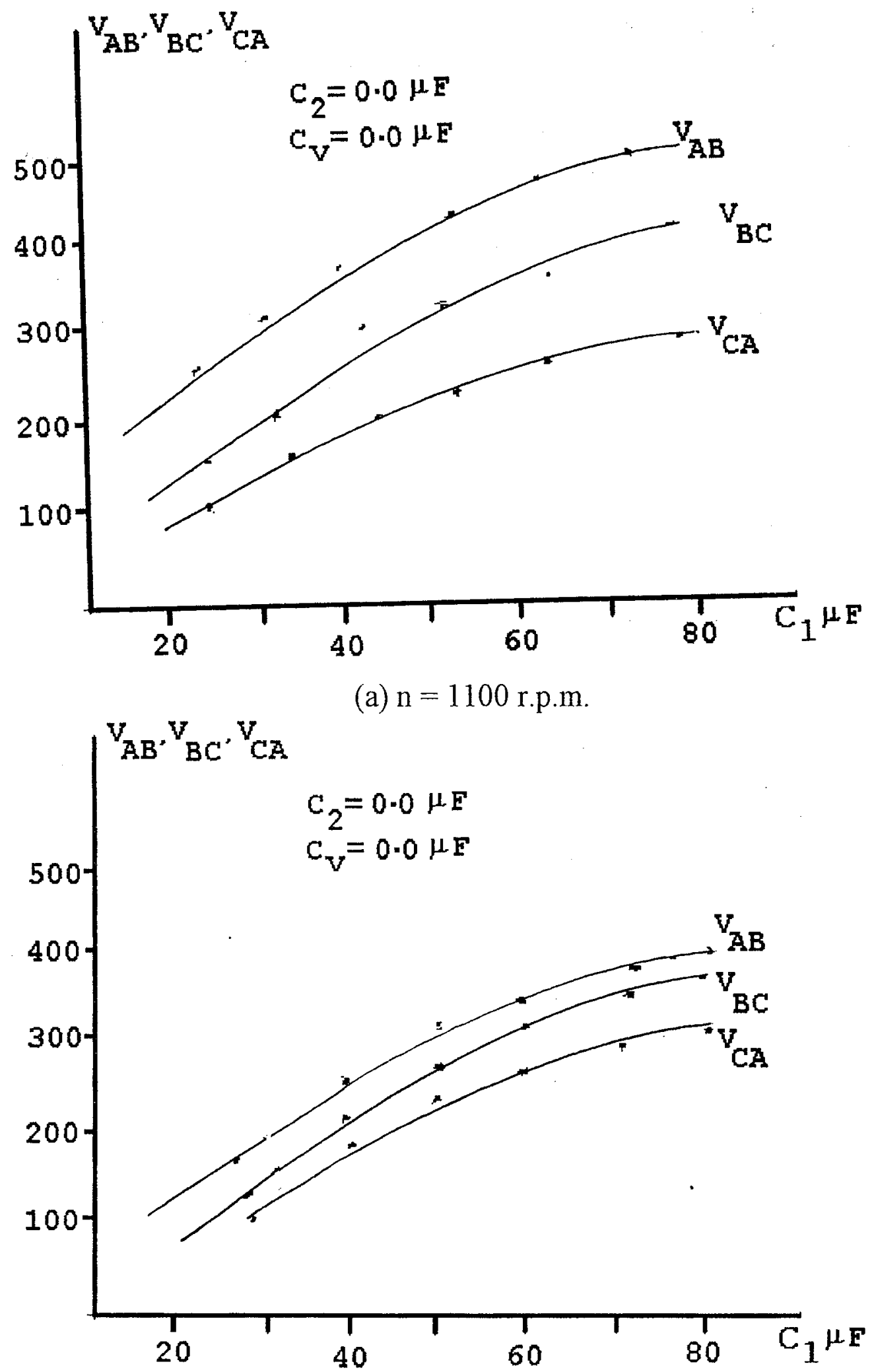

(b) $\mathrm{n}=1000$ r.p.m.

Figure (2) Variation of terminal voltages versus $C_{1}$ for rotor speed at no load without voltage regulators $\left(\mathrm{C}_{\mathrm{V}}=0 \mu \mathrm{F}, \mathrm{L}_{\mathrm{V}}=0 \mathrm{H}\right)$ 


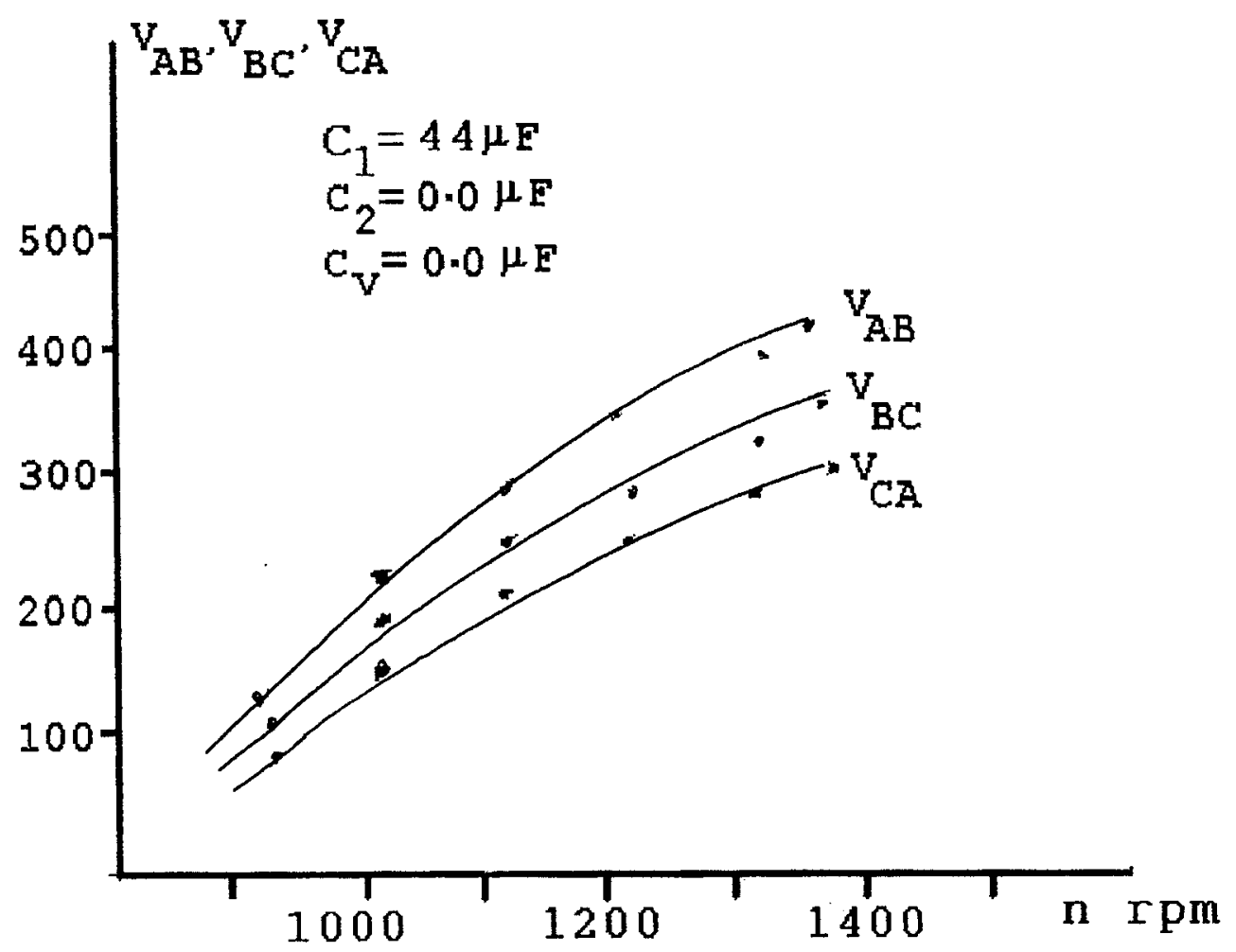

Figure (3) Variation of terminal voltages versus rotor speed at no load with $\mathrm{C}_{1}=44 \mu \mathrm{F}, \mathrm{C}_{2}=0 \mu \mathrm{F}, \mathrm{C}_{\mathrm{v}}=0 \mu \mathrm{F}$ )

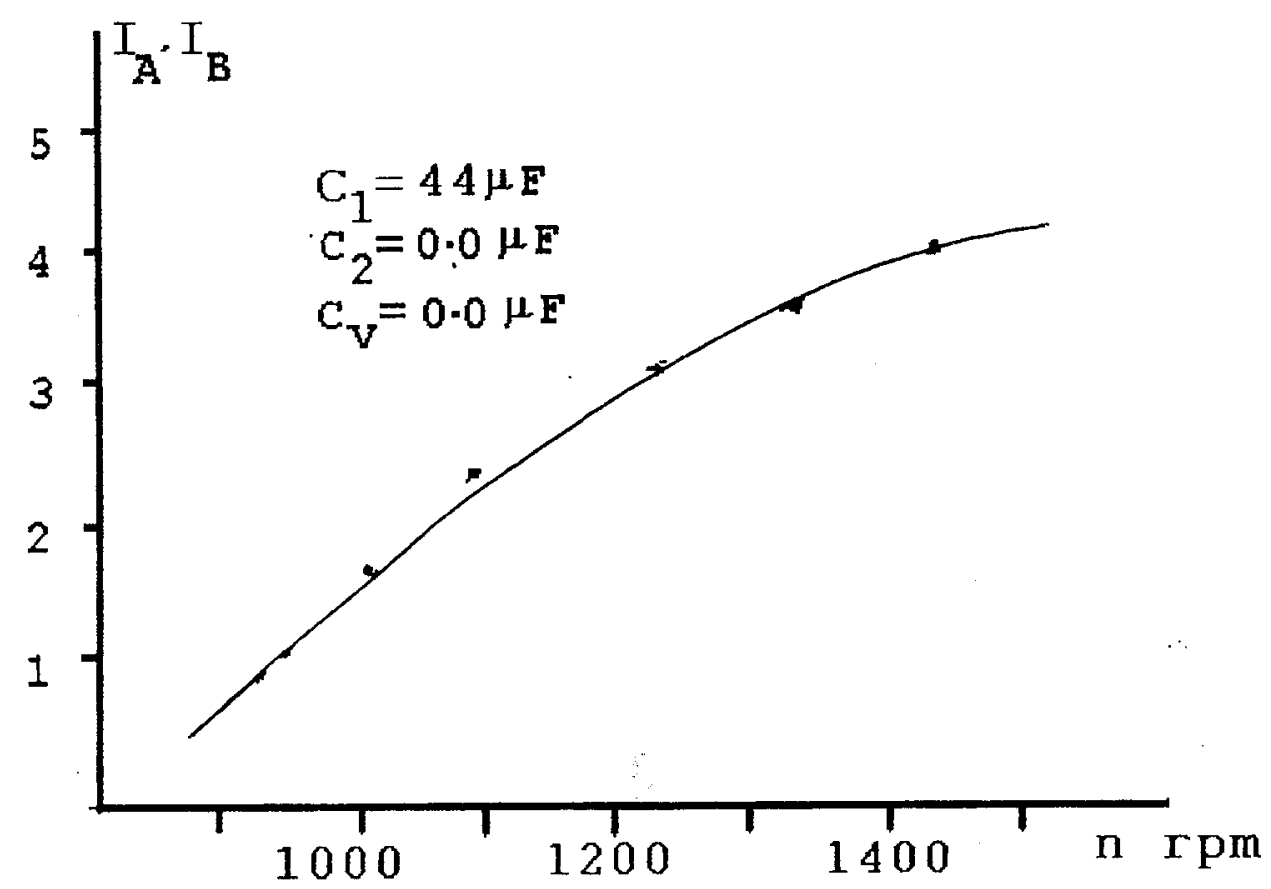

Figure (4) Variation of winding currents versus rotor speed at no load with $\mathrm{C}_{1}=44 \mu \mathrm{F}, \mathrm{C}_{2}=0 \mu \mathrm{F}, \mathrm{C}_{\mathrm{v}}=0 \mu \mathrm{F}$ ) 


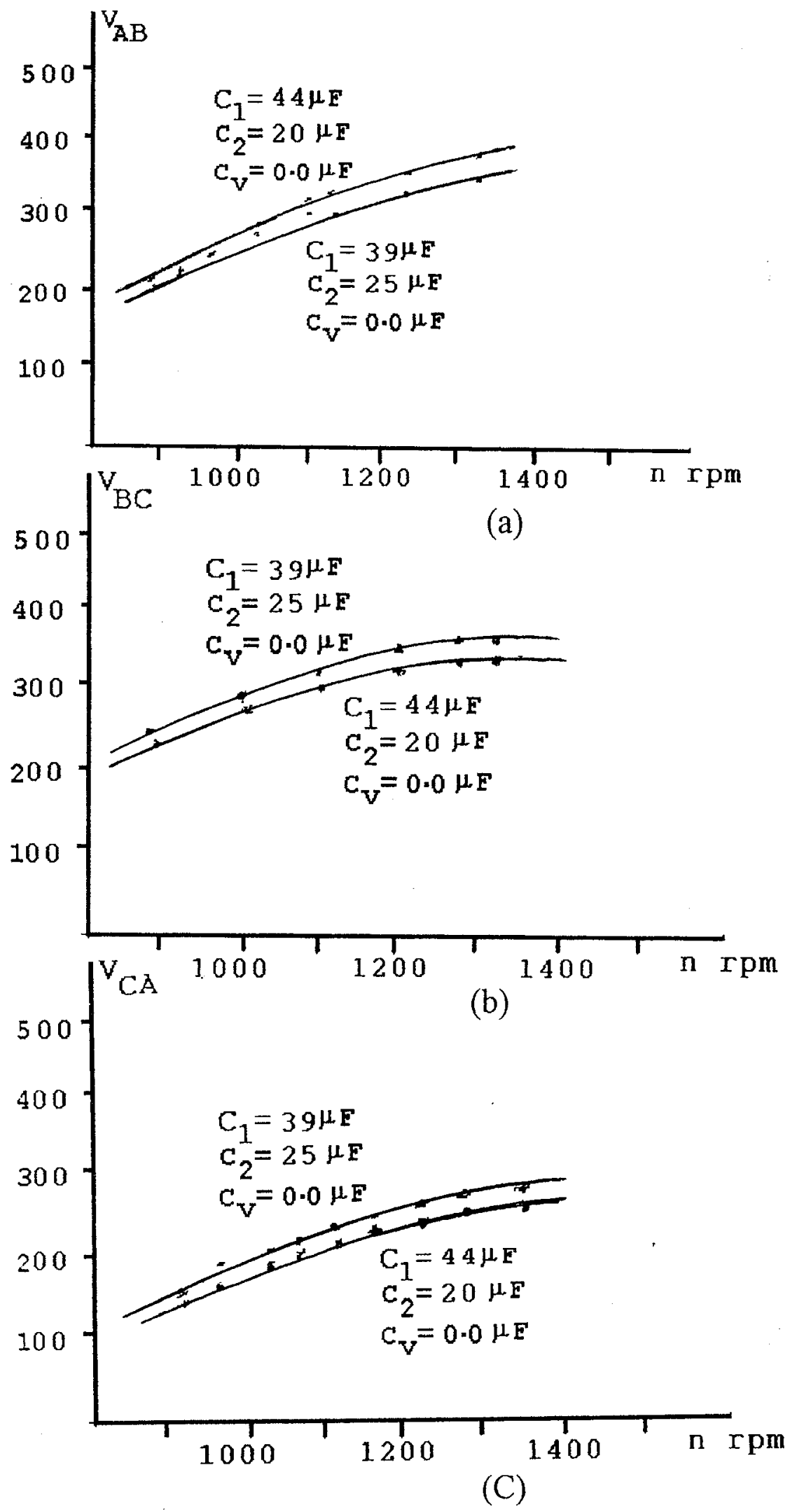

Figure(5) Variation of the terminal voltages versus rotor speed at no load with $\mathrm{C}_{1}=44 \mu \mathrm{F}, \mathrm{C}_{2}=20 \mu \mathrm{F}, \mathrm{C}_{1}=39 \mu \mathrm{F}, \mathrm{C}_{2}=25 \mu \mathrm{F}$ 


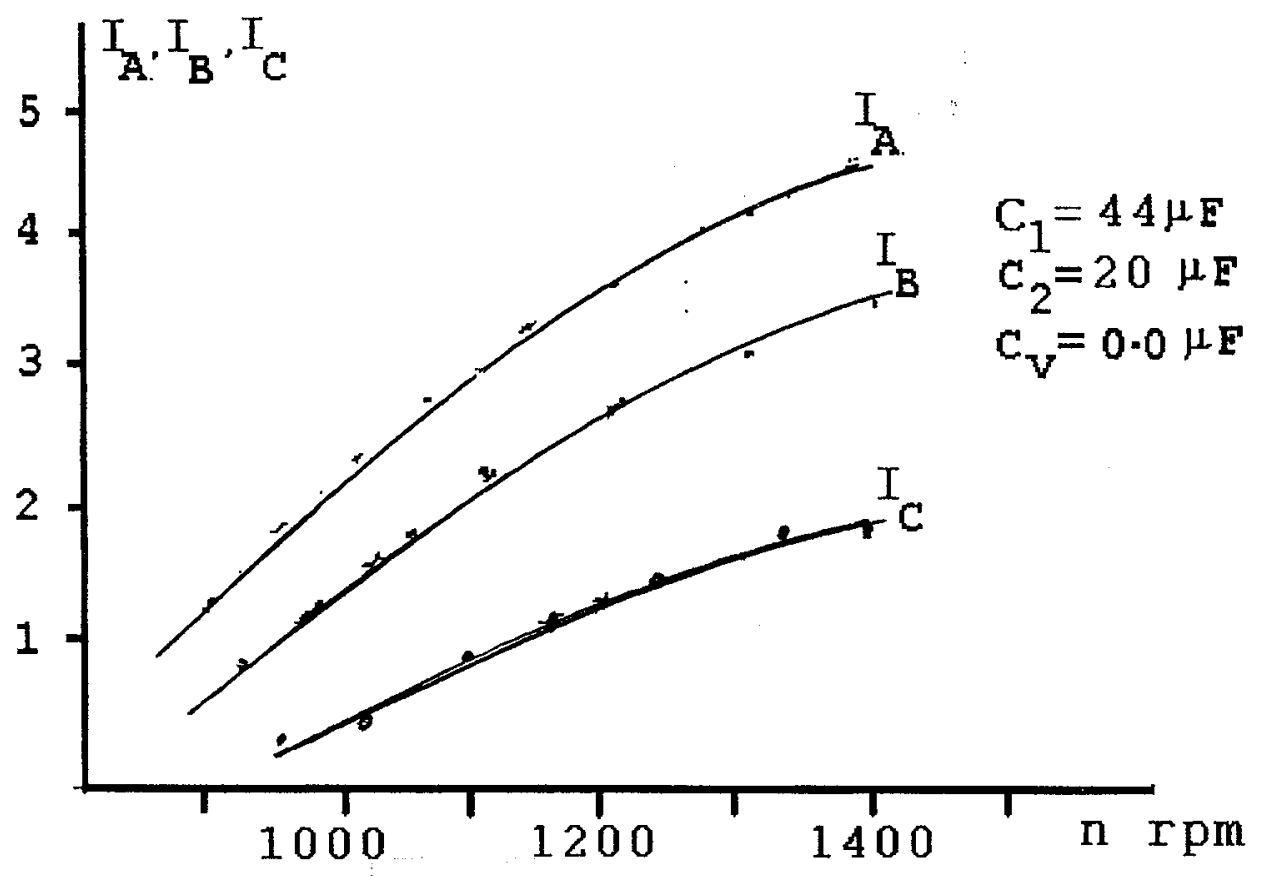

Figure(6) Variation of winding currents versus rotor speed at no load

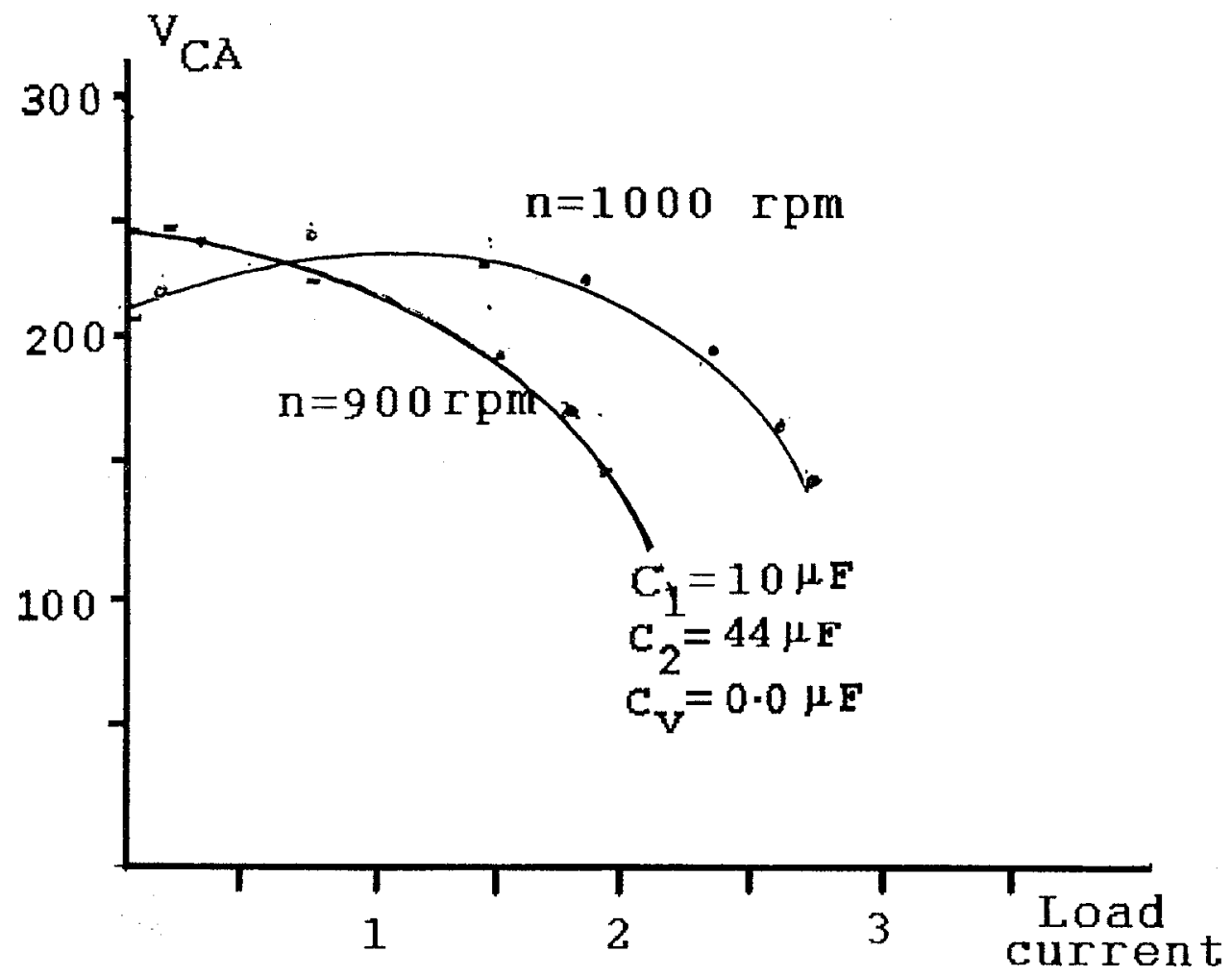

Figure (7) Variation of the terminal voltages versus load current with rotor speed $=(900$ r.p.m. and 1000 r.p.m $)$. 


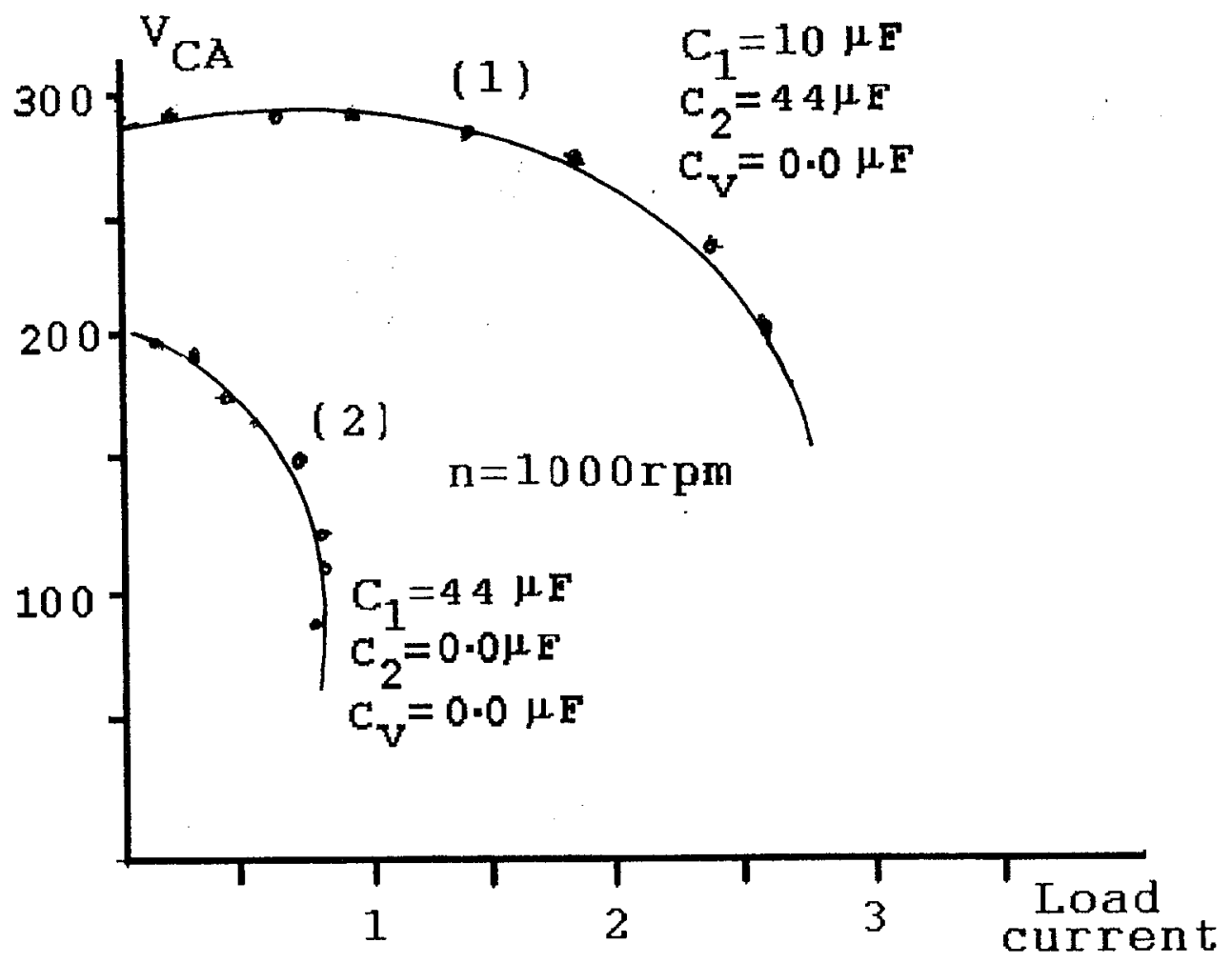

Figure (8) Variation of the terminal voltages versus load current with rotor speed $=1000$ r.p.m.

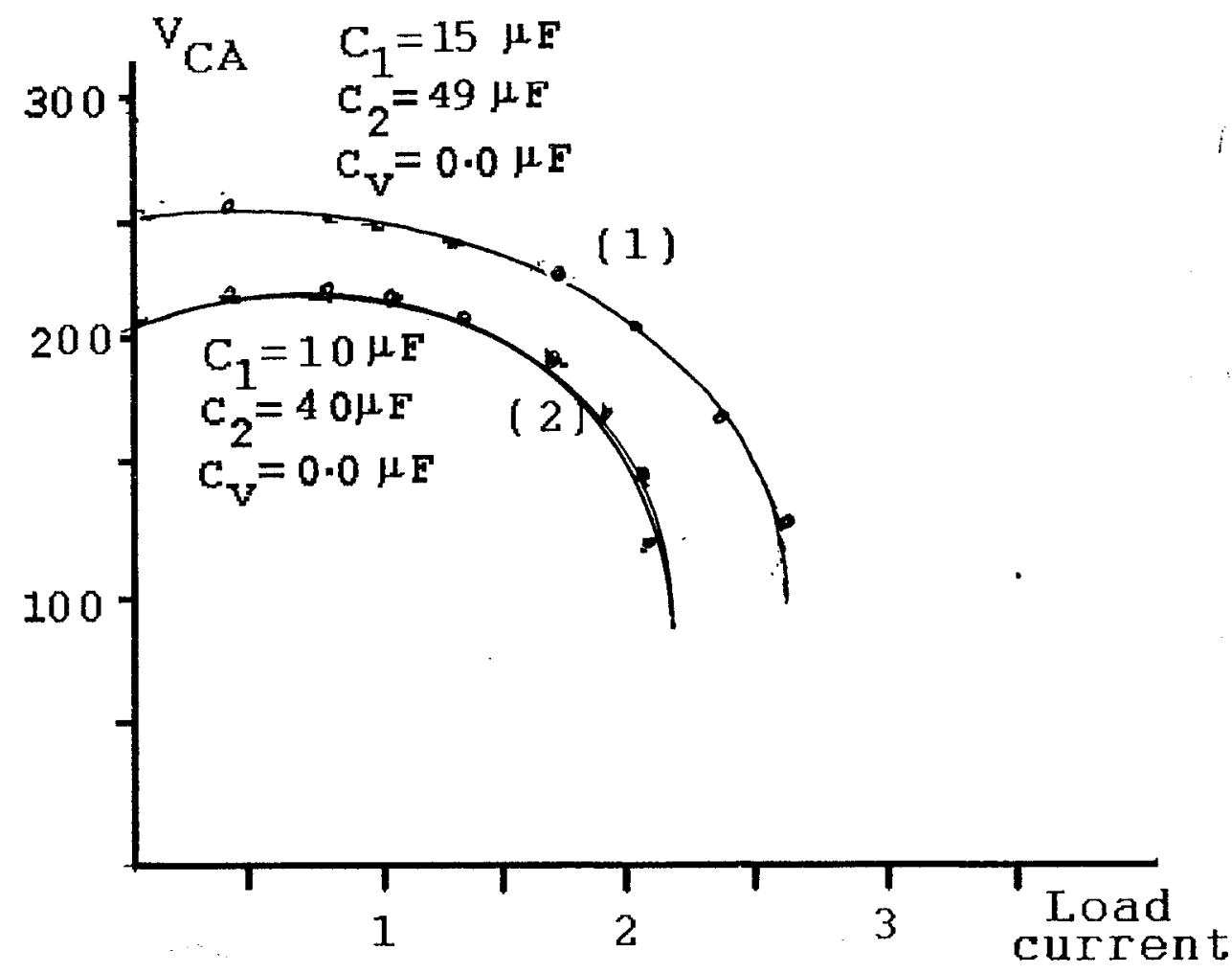

Figure(9) Variation of the terminal voltages versus load current with rotor speed $=900$ r.p.m. at unity power factor. 


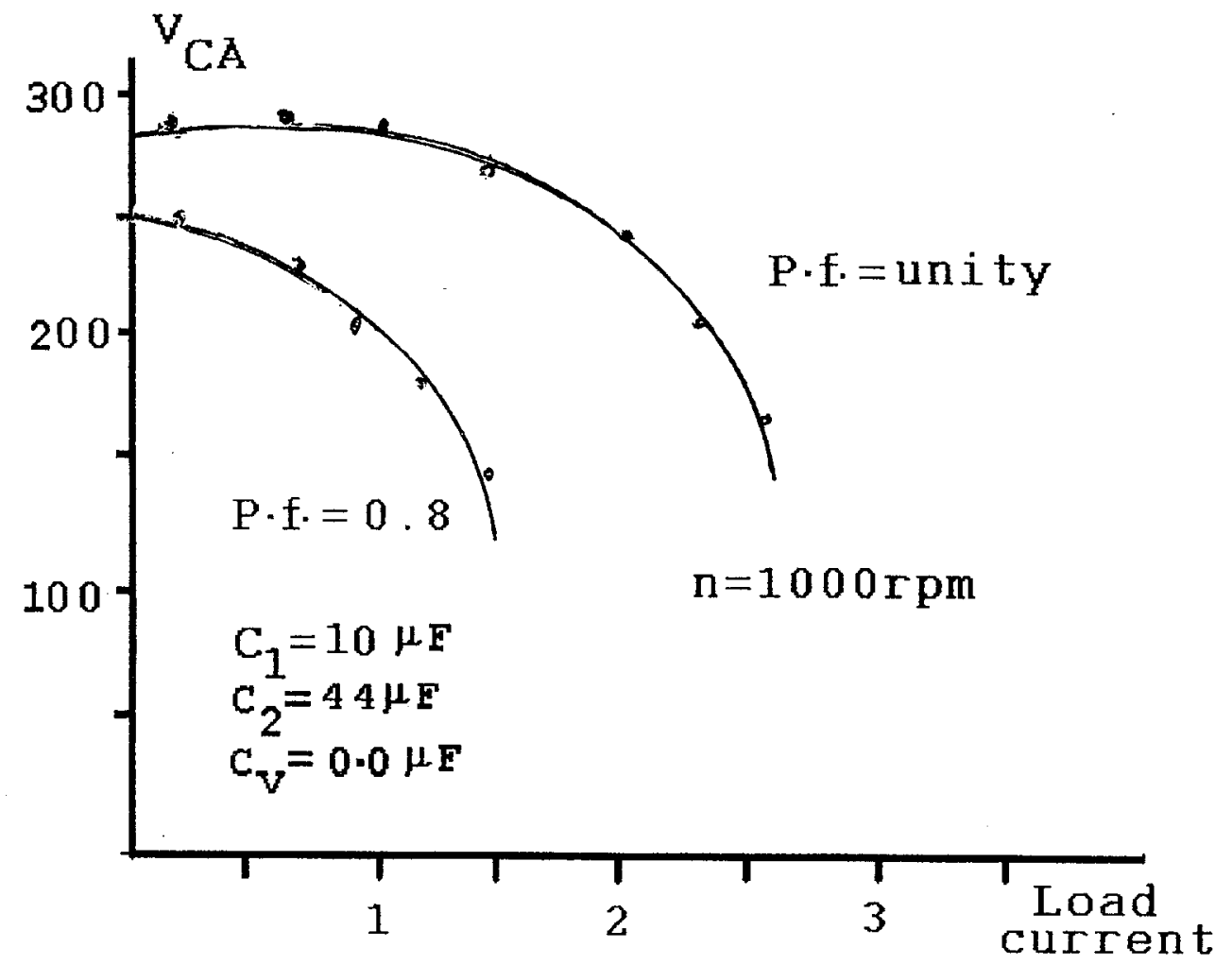

Figure(10) Variation of the terminal voltages versus load current with rotor speed $=1000$ r.p.m. for two different values of p.f.

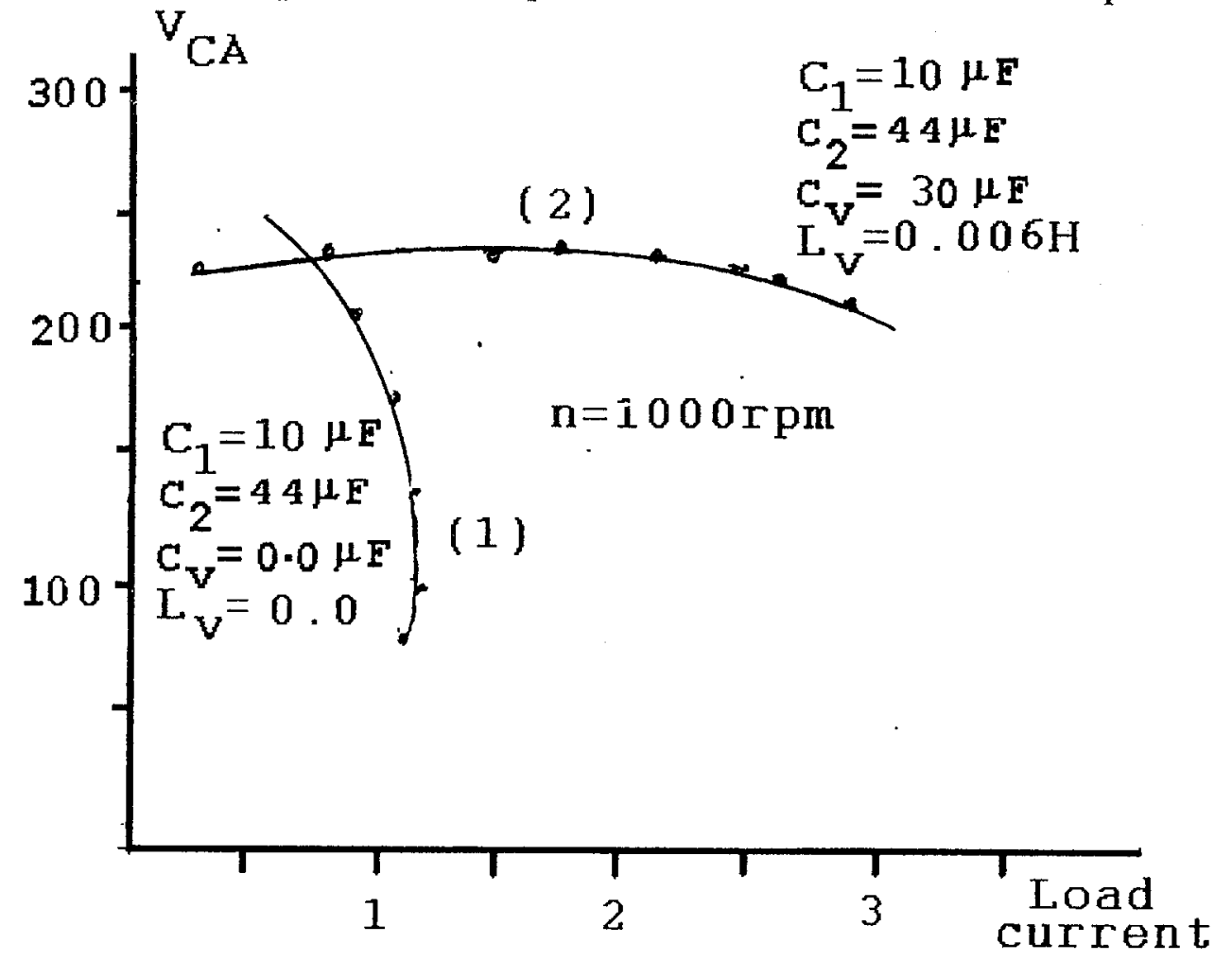

Figure(11) Variation of the terminal voltages versus load current with rotor speed $=1000$ r.p.m. with $\mathrm{C}_{1}=10 \mu \mathrm{F}, \mathrm{C}_{2}=44 \mu \mathrm{F}$ at 0.8 P.F. lag.

With and without voltage regulator (curves 1 and 2 respectively) 


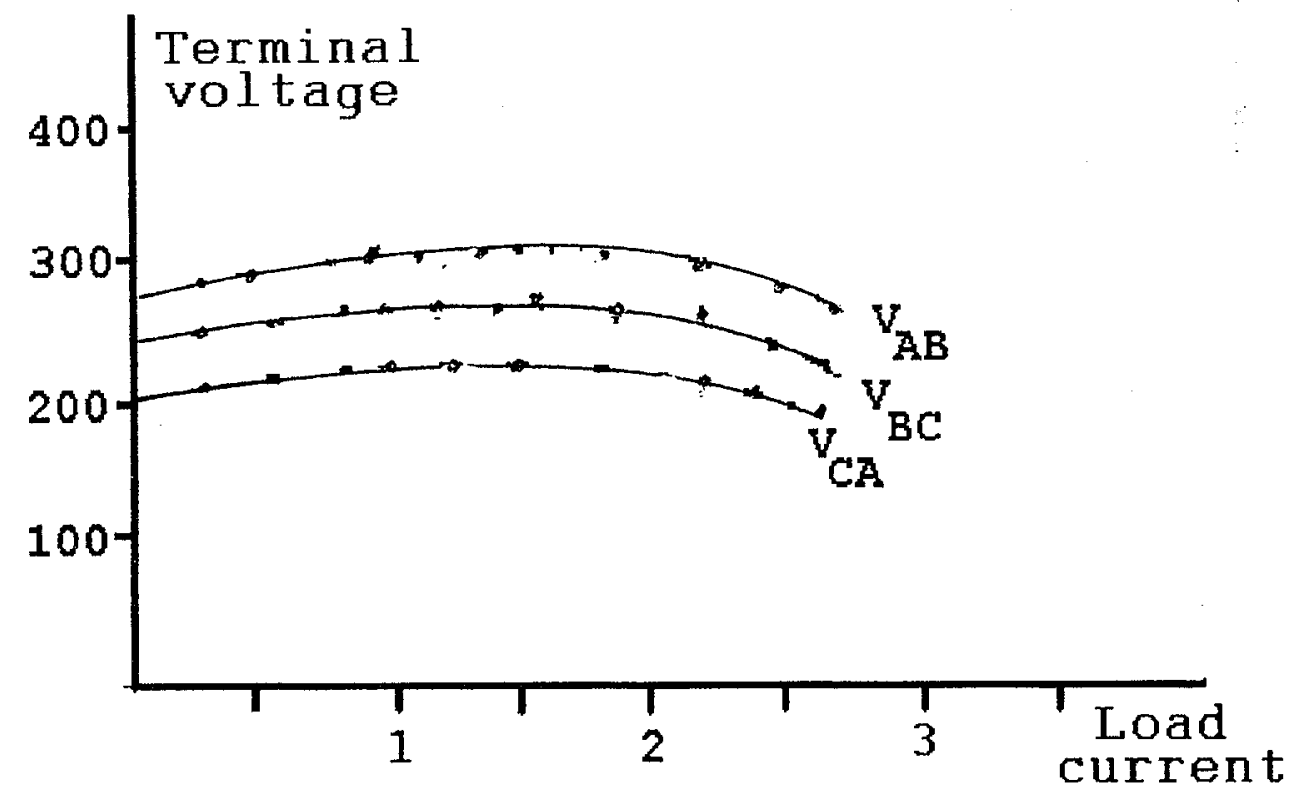

Figure(12) Variation of the terminal voltages versus load current with rotor speed $=1000$ r.p.m. with $\mathrm{C}_{1}=10 \mu \mathrm{F}, \mathrm{C}_{2}=44 \mu \mathrm{F}$ at 0.8 P.F. lag.

With voltage regulator $\left(\mathrm{C}_{\mathrm{V}}=30 \mu \mathrm{F}\right.$ and $\left.\mathrm{L}_{\mathrm{V}}=0.006 \mathrm{H}\right)$ 
تثبيت جها الآلة التأثيرية تلانية الاوجه المتصله كمولد أحادى الوجه

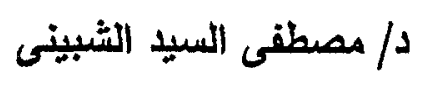

قسم الهذسة الكهربية - كلية الهذلسة بشبين الكوم - جإمعة المنوفيه

ملخص البحث :

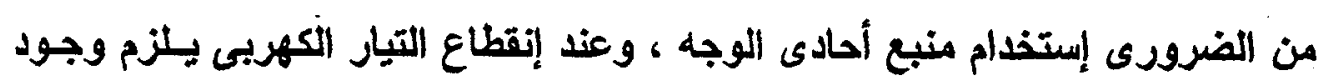

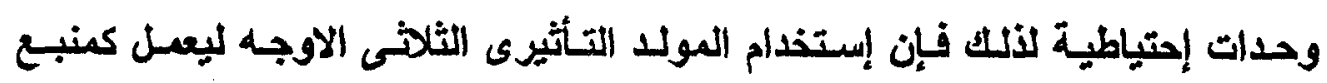

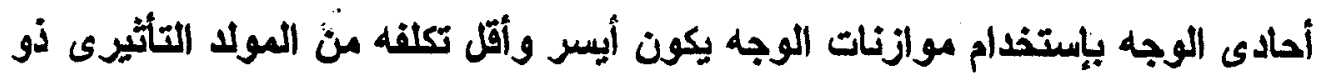

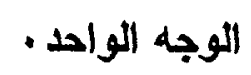

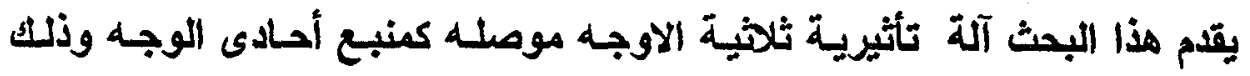

$$
\text { بإستخدام موازنات الوجه . }
$$

يتضمن هذا البحث إجمال إمكاتية العمل لهذا المولـد من خلاهل إستخدام مكثفـات

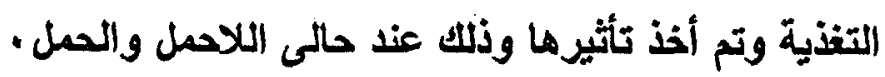

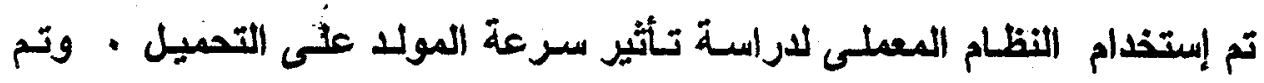

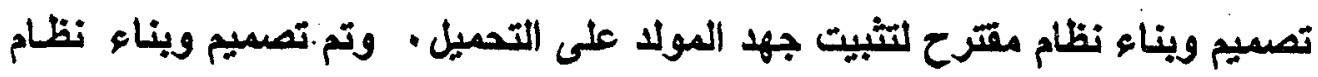

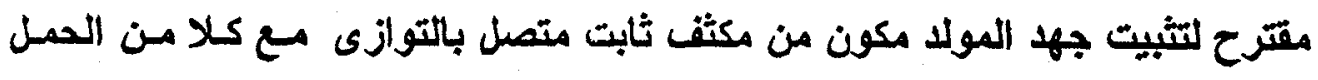

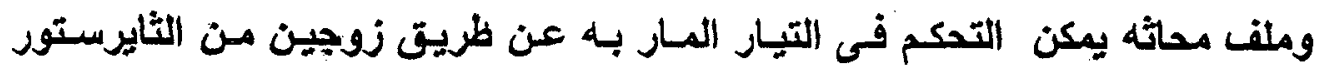

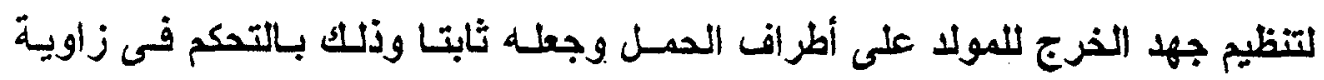

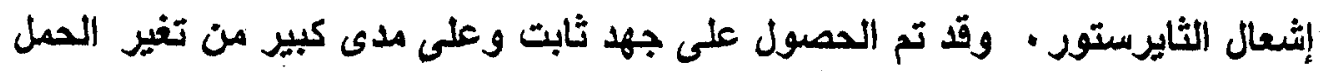

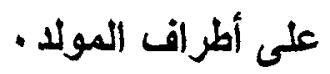

